\title{
PENINGKATAN KEMAMPUAN KETERAMPILAN SALAH SATU PERMAINAN BOLA BESAR (BOLA VOLI) SISWA KELAS XI IPS 1 SMA NEGERI 1 DAWARBLANDONG MOJOKERTO DENGAN MENGGUNAKAN METODE SIMULASI TAHUN PELAJARAN 2019/2020
}

\author{
KUSNO PURWANTO \\ SMA Negeri 1 Dawarblandong Mojokerto \\ e-mail: kusnopurwanto@sman1dawarblandong.org
}

\begin{abstract}
ABSTRAK
Keberhasilan suatu pendidikan jasmani olahraga dan kesehatan dipengaruhi besar oleh adanya metodelogi pembelajaran yang kreatif dan bervariasi. Banyak jenis metode pembelajaran yang digunakan agar dapat meningkatkan hasil belajar siswa, akan tetapi pada kenyataan dan praktik di lapangan, masih banyak siswa yang masih belum memahami materi yang telah disampaikan oleh guru. Untuk itu diperlukan suatu metode pembelajaran yang lain dalam rangka meningkatkan kemampuan dan keterampilan siswa untuk mencapai hasil belajar yang optimal. Begitupun fenomena yang terjadi di kelas XI IPS 1 SMA Negeri 1 Dawarblandong Mojokerto tahun pelajaran 2019/2020 masih banyak siswa yang belum memahami materi salah satu permainan bola besar (bola voli) sehingga dibuktikan dengan hasil belajar yang tergolong rendah. Oleh sebab itu penelitian ini dilakukan berdasarkan rumusan masalah bagaimana peningkatan kemampuan dan keterampilan salah satu permainan bola besar (bola voli) siswa kelas XI IPS 1 SMA Negeri 1 Dawarblandong Mojokerto dengan menggunakan metode simulasi tahun pelajaran 2019/2020. Metode penelitian yang digunakan peneliti, yaitu penelitian tindakan kelas (PTK) dengan pendekatan deskriptif kualitatif. Jenis penelitian tindakan kelas dilaksanakan sebanyak 2 siklus. Adapun rincian dari tiap siklus sebagai berikut: (1) perencanaan; (2) tindakan penelitian; (3) pengamatan; dan (4) refleksi, Hasil dari diskusi tiap siklus menjadi rujukan untuk memperbaiki kegiatan pembelajaran pada tahapan berikutnya. Hasil Penelitian, menunjukkan dari hasil observasi awal atau hasil pra siklus ketuntasan belajar siswa pada kemampuan pengetahuan dan praktik keterampilan hanya $32,35 \%$ meningkat menjadi 55,88\% pada siklus I, sehingga diperlukan tindak lanjut pada siklus II dan pada siklus II ini mengalami peningkatan signifikan sebesar 88,23\%. Hal ini menunjukkan bahwa pada siklus II ini sudah mencapai dan melebihi ketentuan yang teklah ditetapkan oleh sekolah yaitu ketuntasan belajar siswa yaitu $80 \%$. Dapat dikatakan, penggunaan metode simulasi pada pembelajaran permainan bola besar (bola voli) terbukti mengalami peningkatan yang signifikan terhadap hasil belajar siswa sehingga mencapai ketuntasan yang optimal dan dapat mencapai ketentuan yang telah ditetapkan oleh sekolah.
\end{abstract}

Kata Kunci: Metode simulasi, Bola voli

\section{PENDAHULUAN}

Pendidikan Jasmani Olahraga dan Kesehatan (PJOK) merupakan kegiatan pembelajaran melalui aktifitas jasmani yang digunakan sebagai media guna mencapai perkembangan individu secara menyeluruh. Sedangkan menurut Salmi (2018:1) pendidikan jasmani adalah suatu proses pendidikan seseorang sebagai perorangan atau anggota masyarakat yang dilakukan secara sadar dan sistematik melalui berbagai kegiatan jasmani untuk memperoleh pertumbuhan jasmani, kesehatan dan kesegaran jasmani, kemampuan dan keterampilan, kecerdasan dan perkembangan watak, serta kepribadian yang harmonis dalam rangka pembentukan manusia Indonesia berkualitas berdasarkan Pancasila. Kedudukan mata pelajaran PJOK merupakan salah satu kelompok mata pelajaran yang lebih menekankan fisik, sportivitas, disiplin, kerja sama, dan kesadaran hidup sehat. Melalui PJOK kemampuan dan keterampilan pada diri siswa harus dikembangkan secara optimal untuk mendukung pencapaian tujuan pendidikan. Selain itu, pendidikan jasmani yang dilakukan sejak dini merupakan awal pengembangan prsetasi olahraga. Hal ini, menunjukkan betapa pentingnya pembinaan pendidikan jasamani, baik 


\section{TEACHING : Jurnal Inovasi Keguruan dan IImu Pendidikan Vol. 1. No. 3 September 2021 e-ISSN : 2775-7188 | p-ISSN : 2775-717X}

melalui jalur sekolah maupun luar sekolah, yang harus dilakukan sejak usia muda (Ali, 2017:143).

Pada mata pelajaran PJOK, siswa diberikan intruksi ke dalam aktivitas jasmaniah tercantum dalam keterampilan olahraga, maka tidak mengejutkan bila banyak yang meyakini dan mengatakan jika PJOK merupakan bagian pendidikan yang kompleks, dan sekaligus mempunyai kemampuan yang sangat ideal untuk mendidik (Lutan \& Suherman 2000:1). Pada kurikulum pendidikan jasmani, pembelajaran berbagai aktivitas fisik dan olahraga dikelompokkan ke dalam tujuh bahan kajian, yaitu: (1) Aktivitas permainan dan olahraga; (2) Aktivitas pengembangan; (3) Uji diri/senam; (4) Aktivitas ritmik; (5) Aktivitas air/aquatic; (6) Pendidikan luar kelas; (7) Pendidikan Kesehatan (Depdiknas RI, 2003).

Permaianan bola voli merupakan salah satu aktivitas fisik yang berada dalam kelompok aktivitas permainan dan olahraga. Sedangkan menurut Nuril (2007:19) menjelaskan bahwa permainan bola voli merupakan suatu permainan yang kompleks dan tidak mudah dilakukan oleh setiap orang. Permainan bola voli dilakukan oleh dua regu yang saling berhadapan dengan dipisahkan jaring di tengah lapangan dan setiap regu terdiri dari 6 orang yang setiap satu setnya terdiri dari 25 poin dengan sistem rally poin dan dipimpin oleh dua orag wasit (M.Taufiq, 2015:155).

Pada mata pelajaran PJOK materi permainan bola voli termasuk dalam kompetensi dasar permainan bola besar. Dalam permainan bola voli, ada 4 tahapan yang dipelajari salah satunya adalah passing, servis, spike, dan blok. Dalam satu tim sangat sulit untuk bisa meraih keberhasilan/kemenangan saat bermain apabila pemain tidak mempunyai kemampuan ke empat tahapan dengan baik (Pardijono, Hidayat, \& Indahwati, 2011:11). Sedangkan menurut Faridha (2010:4) adalah teknik dasar bola voli terdiri dari bermacam-macam gerakan. Gerakan yang dimaksud di sini adalah gerakan dengan teknik dasar yang dilakukan dengan benar. Penguasaan teknik dasar permainan bola voli antara lain, set up, passing, smash, dan blok (M.Taufik, 2015:155).

Dalam pelaksanaan pembelajaran bola voli, siswa perlu untuk mengerti tahapan atau teknik dasar permainan bola voli. Salah satu penyebab ketidakberhasilan siswa dalam sebuah pembelajaran olahraga adalah siswa tidak mampu mengatasi atau melakukan tugas gerak dan peraturan yang sangat kompleks dalam sebuah olahraga, dalam hal ini bola voli (Ali, 2017:146). Berdasarkan hasil pengamatan guru mata pelajaran PJOK di SMA Negeri 1 Dawarblandong Mojokerto, saat pembelajaran berlangsung hanya sebagian kecil siswa saja yang memahami materi dan tidak sanggup mengatasi tugas gerak karena siswa cenderung merasa jenuh dengan pembelajaran dikarenakan pembelajaran terkesan statis dan monoton. Kondisi seperti ini yang menyebabkan kemampuan hasil belajar/nilai siswa mengalami ketimpangan dan cenderung rendah.

Begitupun saat uji keterampilan bola voli yang mencakup 4 tahapan yaitu servis, passing bawah, passing atas, dan smash, masih banyak siswa yang belum menguasai dengan baik, dan rata-rata nilai yang didapatkan kurang dari KKM minimal 66 yang ditinjau hasil penilaian dari aspek pengetahuan, sikap, dan keterampilan siswa. Fenomena yang terjadi di kelas XI IPS 1 SMA Negeri 1 Dawarblandong Mojokerto pada tahun pelajaran 2019/2020 adalah banyak siswa yang takut dan tidak percaya diri saat melakukan 4 tahapan dalam permainan bola voli. Ketika melakukan gerakan servis siswa kesulitan dalam melakukan gerakan ayunan tangan dan perkenaan bola serta timing dengan bola, banyak siswa yang melakukan servis tidak tepat pada telapak tangan. Saat melakukan passing bawah dan atas siswa juga kesulitan dalam mempraktikkan gerakan tangan dan perkenaan bola. Untuk smash siswa juga mengalami kesulitan karena cenderung ragu-ragu ketika melompat dan perkenaan bola saat di udara yaitu timing antara arah bola dan ayunan tangan.

Keberhasilan Proses Belajar Mengajar (PBM) tergantung pada metodelogi atau cara mengajar guru. Beberapa macam metode pembelajaran antara lain, metode diskusi, metode demonstrasi, metode simulasi, dan lain-lainnya. Setiap metode pembelajaran memiliki penekanan dan variasi pembelajaran yang berbeda sehingga guru dapat menentukan metode 
sesuai dengan materi pembelajaran yang akan diajarkan. Simulasi merupakan suatu bentuk strategi pembelajaran yang difokuskan pada kegiatan aktif dan praktik siswa yang mengarah pada pemahaman dan penguasaan materi pembelajaran melalui aktivitas nyata dan terwujud dalam sebuah pola pembelajaran yang efektif dan efisien. Menurut Sudjana (2013:89) kata simulation atinya tiruan atau perbuatan yang pura-pura. Dengan demikian simulasi dalam metode mengajar dimaksudkan sebagai cara untuk menjelaskan sesuatu (bahan pelajaran) melalui perbuatan yang bersifat pura-pura atau melalui proses tingkah laku imitasi, atau bermain peranan mengenai suatu tingkah laku yang dilakukan seolah-olah dalam keadaan yang sebenarnya.

Langkah-langkah pelaksanaan metode simulasi dalam permainan bola voli adalah (a) guru menetapkan topik atau masalah serta tujuan yang hendak dicapai oleh simulasi; (b) guru memberikan gambaran masalah dalam situasi yang akan disimulasikan; (c) guru membentuk kelompok dan menentukan alat yang digunakan; (d) guru menetapkan pemain yang akan terlibat dalam situasi; (e) guru memberika kesempatan kepada siswa untuk bertanya khususnya kepada siswa yang saat simulasi; (f) simulai dimulai dan siswa lainnya mengikuti dengan penuh perhatian; (g) guru dan siswa melakukan diskusi baik tentang jalannya simulasi maupun materi yang disimulasikan; dan( h) guru merusmuskan kesimpulan.

Pemilihan metode simulasi yang mempunyai ciri khas yaitu dengan memainkan peran di luar dirinya maka siswa akan memperoleh pengalaman belajar yang mendekati situasi nyata dan sebenarnya. Sehingga siswa diharapkan semakin semangat, antusias, serta aktif dikarenakan situasi pembelajaran yang berbeda. Maka, sebagai guru pengajar mata pelajaran PJOK, peneliti memilih metode simulasi untuk meningkatan kemampuan dan keterampilan siswa pada salah satu permainan bola besar (bola voli) siswa kelas XI IPS 1 SMA Negeri 1 Dawarblandong Mojokerto tahun pelajaran 2019/2020.

\section{METODE PENELITIAN}

Metode penelitian yang digunakan dalam penelitian yang berjudul Peningkatan Kemampuan dan Keterampilan Salah Satu Permainan Bola Besar (bola voli) Siswa Kelas XI IPS 1 SMA Negeri 1 Dawarblandong Mojokerto dengan Menggunakan Metode Simulasi Tahun Pelajaran 2019/2020 adalah penelitian tindakan kelas (PTK) dengan pendekatan deskriptif kualitatif. Menurut Sugiyanto (1995: 61) metode deskriptif dirancang untuk mengumpulkan informasi tentang keadaan-keadaan nyata sekarang (sedang berlangsung). Sedangankan penelitian kualitatif (Qualitative research) merupakan suatu penelitian yang ditujukan untuk mendeskripsikan dan menganalisis fenomena, peristiwa, aktivitas sosial, sikap, kepercayaan, persepsi, pemikiran orang secara individual maupun kelompok. Sesuai dengan tujuan, penelitian ini menggunakan Penelitian Tindakan Kelas (PTK). Menurut Arikunto (2006: 96) penelitian tindakan kelas (PTK) merupakan penilitian yang dilakukan Oleh guru di kelas atau di sekolah tempat guru tersebut mengajar dengan penekanan pada penyempurnaan atau peningkatan proses dan praksis pembelajaran. Adapun tujuan utama dari PTK adalah untuk memperbaiki/meningkatkan praktik pembelajaran secara berkesinambungan, sedangkan tujuan penyertaannya adalah menumbuhkan budaya meneliti di kalangan guru (Mukhlis, 2000: 5). Berikut ini merupakan dasar yang penulis gunakan dalam melakukan siklus penelitian. 


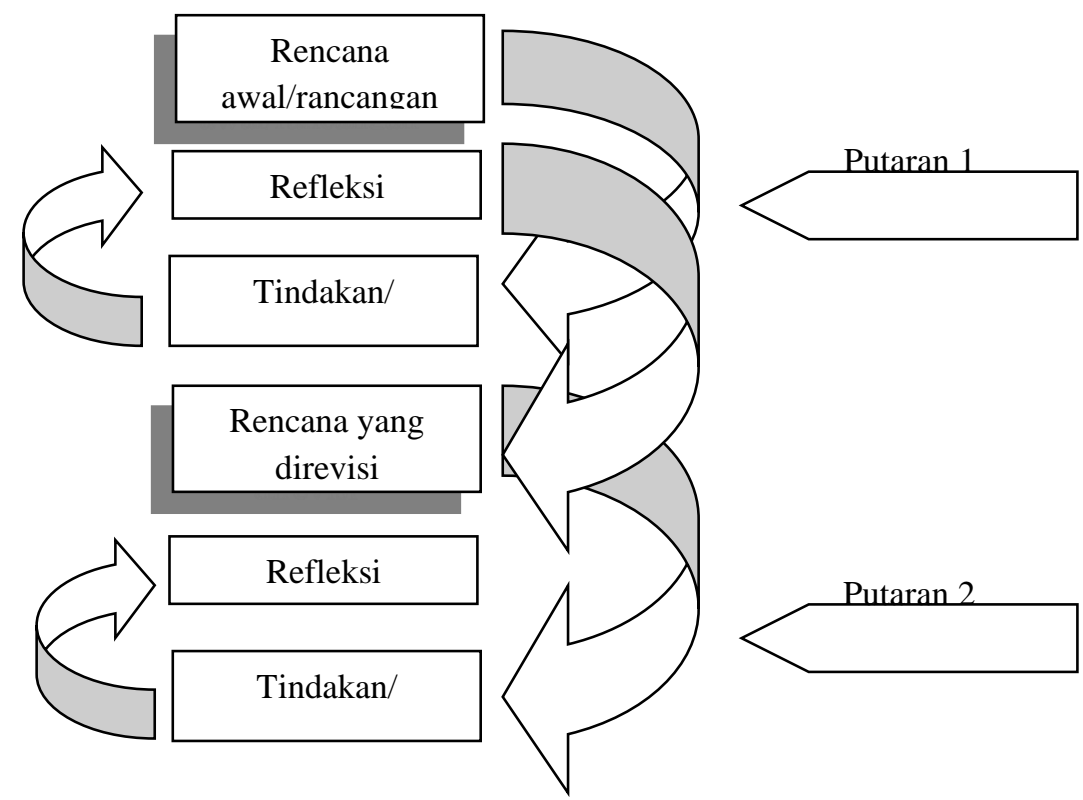

Gambar 1. Skema Penelitian Tindakan Kelas

Penelitian Tindakan Kelas (PTK) dilaksanakan mulai Senin, 5 Agustus 2019 sampai dengan 16 September 2019 dan melalui beberapa siklus. Subyek dari penelitian ini adalah siswa kelas XI IPS 1 SMA Negeri 1 Dawarblandong Mojokerto. Setiap siklus dilaksanakan tahap perencanaan (planning), pelaksanaan tindakan (action), pengamatan (observation), dan refleksi (reflektion). Data tentang kemampuan siswa diambil dari penilaian pemahaman konsep menggunakan tes pengetahuan (uji tulis), dan tes keterampilan (uji praktik). Dalam penelitian ini, peneliti berkolaborasi dengan guru pendidikan jasmani yang lain serta dengan kepala sekolah. Peneliti terlibat langsung dalam penelitian mulai dari awal sampai penelitian berakhir. Peneliti berusaha melihat, mengamati, merasakan, menghayati, merefleksi, dan mengevaluasi kegiatan pembelajaran yang berlangsung. Peneliti bertindak sebagai perencana, pengumpul data, penganalisis data, penafsir data dan sebagai pelapor hasil penelitian.

\section{HASIL DAN PEMBAHASAN}

\section{Hasil}

Berdasarkan hasil penelitian, kemampuan dan keterampilan salah satu permainan bola besar (bola voli) siswa kelas XI IPS 1 SMA Negeri 1 Dawarblandong Mojokerto tahun pelajaran 2019/2020 masih tergolong rendah. Hal ini terbukti dengan hasil observasi awal (pra siklus) kemampuan dan keterampilan salah satu permainan bola besar (bola voli) siswa kelas XI IPS 1 SMA Negeri 1 Dawarblandong Mojokerto tahun pelajaran 2019/2020. Berikut tabel hasil nilai ketercapaian siswa kelas XI IPS 1 pada pembelajaran bola besar (bola voli) pra siklus.

Tabel 1. Hasil Ketercapaian Nilai Siswa Kelas XI IPS 1 pada Pembelajaran Bola Besar (Bola Voli) Pra Siklus

\begin{tabular}{|c|c|c|c|c|c|c|}
\hline \multirow{2}{*}{ NO } & \multirow{2}{*}{$\begin{array}{c}\text { SUBJEK } \\
\text { PENELITIAN }\end{array}$} & \multicolumn{2}{|c|}{ NILAI } & \multirow{2}{*}{$\begin{array}{l}\text { NILAI } \\
\text { AKHIR }\end{array}$} & \multicolumn{2}{|c|}{$\begin{array}{c}\text { KETUNTASAN } \\
\text { BELAJAR }\end{array}$} \\
\hline & & PENGETAHUAN & PRAKTIK & & TUNTAS & $\begin{array}{c}\text { BELUM } \\
\text { TUNTAS }\end{array}$ \\
\hline 1 & Siswa A & 59 & 66 & 63 & & $\mathrm{~V}$ \\
\hline 2 & Siswa B & 52 & 68 & 60 & & V \\
\hline 3 & Siswa C & 60 & 70 & 65 & & V \\
\hline 4 & Siswa D & 78 & 70 & 74 & V & \\
\hline 5 & Siswa E & 62 & 64 & 63 & & V \\
\hline 6 & Siswa F & 70 & 70 & 70 & V & \\
\hline 7 & Siswa G & 63 & 68 & 66 & V & \\
\hline
\end{tabular}




\begin{tabular}{|c|c|c|c|c|c|c|}
\hline 8 & Siswa H & 70 & 58 & 64 & & V \\
\hline 9 & Siswa I & 64 & 60 & 62 & & V \\
\hline 10 & Siswa J & 72 & 50 & 61 & & V \\
\hline 11 & Siswa K & 80 & 82 & 81 & V & \\
\hline 12 & Siswa L & 68 & 70 & 69 & $\mathrm{~V}$ & \\
\hline 13 & Siswa M & 60 & 65 & 63 & & $\mathrm{~V}$ \\
\hline 14 & Siswa N & 70 & 80 & 75 & V & \\
\hline 15 & Siswa O & 56 & 70 & 63 & & V \\
\hline 16 & Siswa P & 60 & 65 & 63 & & V \\
\hline 17 & Siswa Q & 45 & 56 & 51 & & $\mathrm{~V}$ \\
\hline 18 & Siswa R & 55 & 70 & 63 & & V \\
\hline 19 & Siswa $\mathrm{S}$ & 78 & 65 & 72 & V & \\
\hline 20 & Siswa T & 48 & 60 & 54 & & V \\
\hline 21 & Siswa U & 52 & 65 & 59 & & V \\
\hline 22 & Siswa V & 72 & 80 & 76 & $\mathrm{~V}$ & $\mathrm{~V}$ \\
\hline 23 & Siswa W & 56 & 65 & 61 & & V \\
\hline 24 & Siswa X & 55 & 68 & 62 & & $\mathrm{~V}$ \\
\hline 25 & Siswa Y & 84 & 85 & 85 & V & \\
\hline 26 & Siswa Z & 75 & 78 & 77 & V & \\
\hline 27 & Siswa AB & 65 & 60 & 63 & & V \\
\hline 28 & Siswa AC & 45 & 70 & 58 & & $\mathrm{~V}$ \\
\hline 29 & Siswa AD & 48 & 60 & 54 & & V \\
\hline 30 & Siswa AE & 45 & 68 & 57 & & V \\
\hline 31 & Siswa AF & 76 & 70 & 73 & V & V \\
\hline 32 & Siswa AG & 58 & 60 & 59 & & V \\
\hline 33 & Siswa AH & 60 & 60 & 60 & & V \\
\hline 34 & Siswa AI & 52 & 60 & 60 & & $\mathrm{~V}$ \\
\hline \multicolumn{3}{|c|}{$\begin{array}{c}\text { JUMLAH NILAI } \\
\text { RATA-RATA } \\
\text { PROSENTASE RATA-RATA }\end{array}$} & & $\begin{array}{c}2199 \\
64,67 \\
64.67 \%\end{array}$ & $\begin{array}{c}11 \\
32.35 \%\end{array}$ & $\begin{array}{c}23 \\
67.64 \%\end{array}$ \\
\hline
\end{tabular}

Dari tabel tersebut dapat dijelaskan ketercapaian hasil belajar siswa dengan jumlah 34 siswa memiliki rata-rata sebesar 64,67\% dengan nilai tertinggi 85 dan nilai terendah 51. Selain itu masih banyak siswa yang belum mencapai KKM yang telah ditetapkan sekolah sebesar 66 sehingga untuk ketuntasan belajar siswa tergolong rendah, yaitu jumlah yang mencapai KKM hanya 11 siswa dengan presentase sebesar 32,35\%, sedangkan siswa yang belum tuntas sebanyak 23 siswa dengan presentase 67,64\%. Berikut adalah gambar diagram ketercapaian ketuntasan hasil belajar siswa pada salah satu materi bola besar (bola voli).

KETUNTASAN HASIL BELAJAR SISWA

KELAS XI IPS 1 MATERI BOLA VOLI PADA PRA SIKLUS

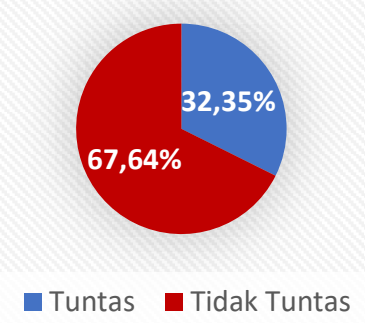

\section{Gambar 2. Diagram Ketuntasan Hasil Belajar Siswa Kelas XI IPS 1 pada Materi Bola Voli Pra siklus}

\section{Siklus 1}

Siklus I dilaksanakan sebanyak 2 kali pertemuan, untuk pertemuan pertama terkait pembelajaran materi teori dan pertemuan kedua terkait simulasi praktik serta terdiri dari 
beberapa tahap yaitu: Perencanaan, (1) Menetapkan topik pembelajaran, KD 3.1 Menganalisis dan mengkategorikan keterampilan gerak salah satu permainan bola besar serta menyusun rencana perbaikan dan 4.1 Mempraktikkan perbaikan keterampilan salah satu permainan bola besar sesuai hasil análisis dan kategorisasi; (2) Menyusun Rencana Pelaksaan Pembelajaran (RPP); (3) Menyiapkan media pembelajaran; (4) Menyiapkan LKS dan lembar kerja; (5) Menetapkan pembagian kelompok diskusi materi simulasi (bola voli); (6) Menyiapkan lembar observasi; dan (7) Menyiapkan lembar rekapitulasi hasil tes pengetahuan dan tes praktik. Pelaksaan Tindakan, (1) Menjelaskan materi pembelajaran salah satu bola besar (bola voli). Siswa mempersiapkan diri di lapangan. Guru selanjutnya mengkondisikan siswa untuk menerima materi pelajaran bolavoli, kemudian melakukan simulasi teknik dasar bermain bola voli (passsing atas, pasing bawah, servis dan smash), setelah itu dilakukan proses simulasi oleh siswa. Setelah itu dilakukan sesi tanya jawab terkait jalannya simulasi maupun materi yang disimulasikan; (2) Memberikan soal latihan terkait materi simulasi; dan (3) Mengidentifikasi kesulitan yang dihadapi siswa serta memberi penguatan strategi pemecahan soal dan teknik bola voli yang tepat.

Observasi, Pada tahap ini dilaksanakan proses observasi terhadap pelaksanaan proses belajar mengajar dan mengadakan penilaian untuk mengetahuin peningkatan kemampuan dan keterampilan salah satu permainan bola besar (bola voli) siswa kelas XI IPS 1 SMA Negeri 1 Dawarblandong Mojokerto dengan menggunakan metode simulasi tahun pelajaran 2019/2020. Berikut tabel hasil nilai ketercapaian siswa kelas XI IPS 1 pada pembelajaran bola besar (bola voli) siklus 1 dengan menggunakan metode simulasi.

Tabel 2. Hasil Ketercapaian Nilai Siswa Kelas XI IPS 1 pada Pembelajaran Bola Besar (Bola Voli) Siklus 1 dengan Menggunakan Metode Simulasi

\begin{tabular}{|c|c|c|c|c|c|c|}
\hline \multirow{2}{*}{$\begin{array}{l}\mathbf{N} \\
\mathbf{O}\end{array}$} & \multirow{2}{*}{$\begin{array}{c}\text { SUBJEK } \\
\text { PENELITIAN }\end{array}$} & \multicolumn{2}{|c|}{ NILAI } & \multirow{2}{*}{$\begin{array}{c}\text { NILAI } \\
\text { AKHI } \\
\quad \mathbf{R}\end{array}$} & \multicolumn{2}{|c|}{$\begin{array}{c}\text { KETUNTASAN } \\
\text { BELAJAR }\end{array}$} \\
\hline & & $\begin{array}{c}\text { PENGETAHUA } \\
\mathbf{N}\end{array}$ & $\begin{array}{c}\text { PRAKTI } \\
\text { K }\end{array}$ & & $\begin{array}{l}\text { TUNTA } \\
\mathbf{S}\end{array}$ & $\begin{array}{c}\text { BELUM } \\
\text { TUNTA } \\
\mathbf{S}\end{array}$ \\
\hline 1 & Siswa A & 73 & 75 & 74 & V & \\
\hline 2 & Siswa B & 60 & 68 & 64 & & V \\
\hline 3 & Siswa C & 60 & 70 & 65 & & $\mathrm{~V}$ \\
\hline 4 & Siswa D & 78 & 70 & 74 & V & \\
\hline 5 & Siswa E & 62 & 68 & 65 & & V \\
\hline 6 & Siswa F & 70 & 70 & 70 & V & \\
\hline 7 & Siswa G & 63 & 68 & 66 & V & \\
\hline 8 & Siswa H & 70 & 60 & 65 & & V \\
\hline 9 & Siswa I & 80 & 83 & 82 & V & \\
\hline 10 & Siswa J & 70 & 60 & 65 & & V \\
\hline 11 & Siswa K & 85 & 88 & 87 & V & \\
\hline 12 & Siswa L & 68 & 70 & 69 & V & \\
\hline 13 & Siswa M & 60 & 68 & 64 & & V \\
\hline 14 & Siswa N & 70 & 80 & 75 & V & \\
\hline 15 & Siswa $\mathrm{O}$ & 78 & 75 & 77 & V & \\
\hline 16 & Siswa $\mathrm{P}$ & 60 & 65 & 63 & & V \\
\hline 17 & Siswa Q & 62 & 64 & 63 & & V \\
\hline 18 & Siswa R & 55 & 70 & 63 & & $\mathrm{~V}$ \\
\hline 19 & Siswa $\mathrm{S}$ & 78 & 65 & 72 & V & \\
\hline 20 & Siswa T & 58 & 62 & 60 & & V \\
\hline 21 & Siswa U & 65 & 65 & 65 & & V \\
\hline 22 & Siswa V & 76 & 80 & 78 & V & $\mathrm{V}$ \\
\hline 23 & Siswa W & 70 & 68 & 69 & V & \\
\hline 24 & Siswa X & 55 & 70 & 63 & & V \\
\hline 25 & Siswa Y & 85 & 86 & 86 & V & \\
\hline
\end{tabular}




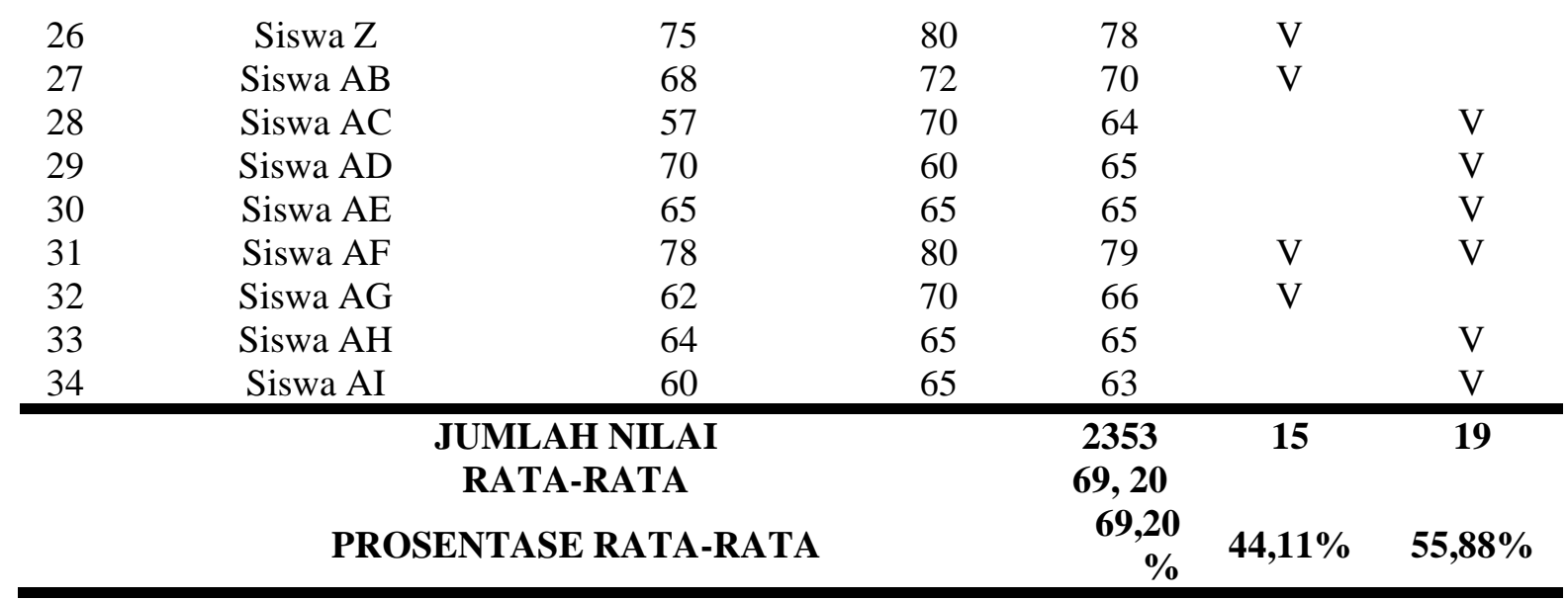

Dari tabel hasil observasi pada siklus I tersebut, setelah diterapkan metode simulasi diperoleh data hasil pembelajaran salah satu permainan bola besar (bola voli) dengan metode simulasi dilakukan melalui 2 tahapan tes, yaitu tes pengetahuan dan tes keterampilan praktik bermain bola voli, diperoleh presentase nilai rata-rata siswa sebesar $69,20 \%$, nilai tertinggi 87 dan nilai terendah 63. Sedangkan siswa tuntas belajar sebanyak 15 siswa sebesar $44,11 \%$ dan 19 siswa belum tuntas belajar atau 55,88\%. Berdasarkan hasil observasi dapat dikatakan bahwa pembelajaran bola voli pada siklus I cukup dan masih memerlukan perbaikan karena belum mencapai $80 \%$ sesuai dengan ketercapaian yang ditetapkan sekolah sebesar $80 \%$. Berikut adalah hasil pembelajaran siklus I terkait peningkatan kemampuan dan keterampilan salah satu bola besar (bola voli) siswa kelas XI IPS 1 SMA Negeri 1 Dawarblandong Mojokerto dengan metode simulasi tahun pelajaran 2019/2020 melalui gambar diagram di bawah ini:

\section{Ketuntasan Hasil Belajar Siswa Kelas XI IPS 1 pada Materi Bola Voli Metode Simulasi Siklus 1}

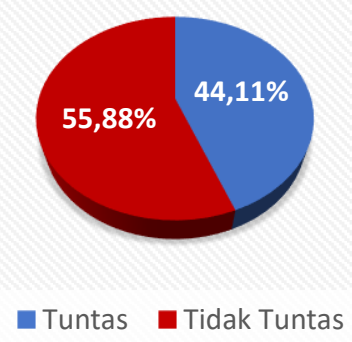

\section{Gambar 3. Diagram Ketuntasan Hasil Belajar Siswa Kelas XI IPS 1 pada Materi Bola Voli Siklus I}

\section{Refleksi}

Pembelajaran menggunakan metode simulasi dapat meningkatkan kemampuan dan keterampilan siswa tentang 4 tahapan salah satu permainan bola besar (bola voli) dan juga siswa tidak bosan dalam melaksanakan pembelajaran. Sehingga siswa lebih termotivasi untuk mencapai target pembelajaran. Hasil observasi pada pembelajaran simulasi siklus 1 adalah (1) masih banyak siswa yang kurang aktif bertanya saat kegiatan simulasi berlangsung; (2) masih banyak siswa yang bergurau dan tidak sungguh-sungguh; dan (3) masih cukup banyak juga siswa yang malu saat ditunjuk untuk melakukan simulasi. Oleh sebab itu perlu ditindak lanjuti pada siklus berikutnya.

\section{Siklus II}

Pada siklus II juga dilaksanakan sebanyak 2 kali pertemuan dan terdiri dari beberapa tahapan yang sama seperti siklus I yaitu: (1) Perencanaan; (2) Pelaksanaan Tindakan; (3) Observasi; dan (4) Refleksi. Persiapan tindakan II didasarkan pada refleksi dari siklus I. Dari 
refleksi I diperoleh bahwa siswa lebih aktif dalam pembelajaran Pendidikan Jasmani, Olahraga dan Kesehatan (PJOK). Hal ini menyebabkan pembelajaran menggunakan simulasi akan tetap dipertahankan, tetapi dengan perbaikan dalam pelaksanaan selanjutnya. Berdasarkan refleksi siklus 1 setelah dilakukan refleksi pada siklus 2 menunjukkan perubahan yang baik seperti: (1) siswa sudah aktif bertanya saat kegiatan materi maupun praktik simulasi; (2) siswa melakukan pemanasan dan praktik simulasi dengan sungguh-sungguh; dan (3) siswa sangat antusias dan bergerak dengan aktif untuk melakukan simulasi yang diarahkan (servis, passing atas, passing bawah, smash). Berikut tabel hasil nilai ketercapaian siswa kelas XI IPS 1 pada pembelajaran bola besar (bola voli) Siklus 2 dengan menggunakan metode simulasi.

Tabel 3. Hasil Ketercapaian Nilai Siswa Kelas XI IPS 1 pada Pembelajaran Bola Besar (Bola Voli) Siklus 2 dengan Menggunakan Metode Simulasi

\begin{tabular}{|c|c|c|c|c|c|c|}
\hline \multirow{2}{*}{$\begin{array}{l}\mathbf{N} \\
\mathbf{O}\end{array}$} & \multirow{2}{*}{$\begin{array}{c}\text { SUBJEK } \\
\text { PENELITIAN }\end{array}$} & \multicolumn{2}{|c|}{ NILAI } & \multirow{2}{*}{$\begin{array}{c}\text { NILAI } \\
\text { AKHI } \\
\quad \mathbf{R}\end{array}$} & \multicolumn{2}{|c|}{$\begin{array}{c}\text { KETUNTASAN } \\
\text { BELAJAR }\end{array}$} \\
\hline & & $\begin{array}{c}\text { PENGETAHUA } \\
\mathbf{N}\end{array}$ & $\begin{array}{c}\text { PRAKTI } \\
\text { K }\end{array}$ & & $\begin{array}{l}\text { TUNTA } \\
\quad \mathbf{S}\end{array}$ & $\begin{array}{c}\text { BELUM } \\
\text { TUNTA } \\
\text { S }\end{array}$ \\
\hline 1 & Siswa A & 81 & 85 & 83 & $\mathrm{~V}$ & \\
\hline 2 & Siswa B & 87 & 82 & 85 & $\mathrm{v}$ & \\
\hline 3 & Siswa C & 79 & 82 & 81 & $\mathrm{v}$ & \\
\hline 4 & Siswa D & 85 & 82 & 84 & V & \\
\hline 5 & Siswa E & 79 & 80 & 80 & $\mathrm{v}$ & \\
\hline 6 & Siswa F & 81 & 78 & 80 & V & \\
\hline 7 & Siswa G & 65 & 64 & 65 & & V \\
\hline 8 & Siswa H & 80 & 80 & 80 & $\mathrm{v}$ & \\
\hline 9 & Siswa I & 82 & 90 & 86 & V & \\
\hline 10 & Siswa J & 90 & 85 & 88 & $\mathrm{v}$ & \\
\hline 11 & Siswa K & 90 & 88 & 89 & V & \\
\hline 12 & Siswa L & 85 & 85 & 85 & V & \\
\hline 13 & Siswa M & 65 & 65 & 65 & & V \\
\hline 14 & Siswa N & 73 & 85 & 79 & V & \\
\hline 15 & Siswa O & 80 & 85 & 83 & V & \\
\hline 16 & Siswa P & 79 & 80 & 80 & $\mathrm{v}$ & \\
\hline 17 & Siswa Q & 81 & 78 & 80 & $\mathrm{v}$ & \\
\hline 18 & Siswa R & 60 & 70 & 65 & & V \\
\hline 19 & Siswa $\mathrm{S}$ & 82 & 78 & 80 & V & \\
\hline 20 & Siswa T & 78 & 85 & 82 & $\mathrm{v}$ & \\
\hline 21 & Siswa U & 78 & 82 & 80 & $\mathrm{v}$ & \\
\hline 22 & Siswa V & 78 & 85 & 82 & V & \\
\hline 23 & Siswa W & 87 & 82 & 85 & V & \\
\hline 24 & Siswa X & 83 & 90 & 87 & $\mathrm{v}$ & \\
\hline 25 & Siswa Y & 90 & 86 & 88 & V & \\
\hline 26 & Siswa Z & 79 & 85 & 82 & V & \\
\hline 27 & Siswa $A B$ & 87 & 82 & 85 & V & \\
\hline 28 & Siswa AC & 60 & 70 & 65 & & V \\
\hline 29 & Siswa AD & 87 & 85 & 86 & $\mathrm{v}$ & \\
\hline 30 & Siswa AE & 81 & 85 & 83 & $\mathrm{v}$ & \\
\hline 31 & Siswa AF & 78 & 82 & 80 & V & \\
\hline 32 & Siswa AG & 86 & 82 & 84 & V & \\
\hline 33 & Siswa AH & 83 & 80 & 82 & $\mathrm{v}$ & \\
\hline 34 & Siswa AI & 62 & 65 & 64 & & V \\
\hline & & $\begin{array}{l}\text { AH NILAI } \\
\text { A-RATA }\end{array}$ & & $\begin{array}{c}2725 \\
80,14\end{array}$ & 29 & 5 \\
\hline
\end{tabular}


Berdasarkan tabel 3 tersebut, hasil pembelajaran pada siklus II diperoleh dengan presentasi ketercapaian nilai rata-rata ketuntasan siswa dari tes pengetahuan dan tes praktik keterampilan sebesar 80,14\%, nilai tertinggi yang diperoleh siswa sebesar 89 dan nilai terendah siswa sebesar 64. Sedangkan siswa tuntas sebanyak 29 siswa dengan presentase sebesar 85,29\% dan hanya 5 siswa belum tuntas atau 14,70\%. Dari hasil ketuntasan tersebut, dapat dikatakan kemampuan dan keterampilan salah satu permainan bola besar (bola voli) siswa pada siklus II sudah mencapai hasil yang baik dan sesuai dengan presentase ketercapaian yang diharapkan sekolah sebesar $80 \%$. Berikut adalah hasil pembelajaran siklus II terkait peningkatan kemampuan dan keterampilan salah satu bola besar (bola voli) siswa kelas XI IPS 1 SMA Negeri 1 Dawarblandong Mojokerto dengan metode simulasi tahun pelajaran 2019/2020 melalui diagram di bawah ini:

\section{Ketuntasan Hasil Belajar Siswa Kelas XI IPS 1 pada Materi Bola Voli Siklus II}

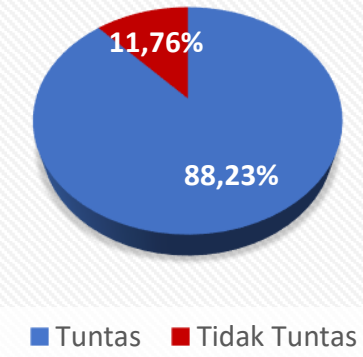

\section{Gambar 4. Diagram Ketuntasan Hasil Belajar Siswa Kelas XI IPS 1 pada Materi Bola} Voli Siklus II

\section{Pembahasan}

Pada pelaksanaan penelitian tindakan kelas ini, adapun langkah-langkah yang dilakukan setiap siklusnya memiliki perubahan beserta hasilnya masing-masing. Secara lebih mendalam, tahapan-tahapan pembelajaran di setiap siklus dalam kegiatan penelitian tindakan kelas (PTK) peningkatan kemampuan dan keterampilan salah satu permainan bola besar (bola voli) siswa kelas XI IPS 1 SMA negeri 1 Dawarblandong Mojokerto tahun pelajaran 2019/2020 melalui metode simulasi mengalami peningkatan yang sangat baik dan signifikan dari tindakan pra siklus hingga siklus II sehingga mampu mencapai hasil pembelaran optimal yang telah ditentukan sekolah. Untuk lebih jelasnya dapat dilihat pada tabel 4 dan gambar grafik 4 berikut ini.

Tabel 4. Diagram Perbandingan Ketuntasan Hasil Belajar Siswa Kelas XI IPS 1 pada Materi Bola Voli

\begin{tabular}{|c|c|c|c|c|c|c|c|c|c|c|}
\hline \multirow[b]{2}{*}{ NO } & \multirow{2}{*}{$\begin{array}{c}\text { SUBJE } \\
\text { K } \\
\text { PENEL } \\
\text { ITIAN }\end{array}$} & \multicolumn{3}{|c|}{ PRA SIKLUS } & \multicolumn{3}{|c|}{ SIKLUS 1} & \multicolumn{3}{|c|}{ SIKLUS 2} \\
\hline & & NA & $\mathbf{T}$ & BT & NA & $\mathbf{T}$ & BT & NA & $\mathbf{T}$ & BT \\
\hline 1 & Siswa A & 63 & & $\mathrm{v}$ & 74 & V & & 83 & V & \\
\hline 2 & Siswa B & 60 & & $\mathrm{v}$ & 64 & & V & 85 & $\mathrm{v}$ & \\
\hline 3 & Siswa C & 65 & & V & 65 & & V & 81 & $\mathrm{v}$ & \\
\hline 4 & Siswa D & 74 & V & & 74 & V & & 84 & V & \\
\hline 5 & Siswa E & 63 & & V & 65 & & V & 80 & $\mathrm{v}$ & \\
\hline 6 & Siswa F & 70 & V & & 70 & V & & 80 & V & \\
\hline 7 & Siswa G & 66 & V & & 66 & V & & 65 & & $\mathrm{v}$ \\
\hline 8 & Siswa H & 64 & & V & 65 & & V & 80 & $\mathrm{v}$ & \\
\hline
\end{tabular}


Vol. 1. No. 3 September 2021 e-ISSN : 2775-7188 | p-ISSN : 2775-717X

\begin{tabular}{|c|c|c|c|c|c|c|c|c|c|c|}
\hline 9 & Siswa I & 62 & & V & 82 & V & & 86 & V & \\
\hline 10 & Siswa J & 61 & & $\mathrm{~V}$ & 65 & & V & 88 & $\mathrm{v}$ & \\
\hline 11 & Siswa K & 81 & V & & 87 & V & & 89 & V & \\
\hline 12 & Siswa L & 69 & $\mathrm{~V}$ & & 69 & $\mathrm{~V}$ & & 85 & $\mathrm{~V}$ & \\
\hline 13 & Siswa M & 63 & & $\mathrm{~V}$ & 64 & & $\mathrm{~V}$ & 65 & & $\mathrm{v}$ \\
\hline 14 & Siswa N & 75 & $\mathrm{~V}$ & & 75 & $\mathrm{~V}$ & & 79 & $\mathrm{~V}$ & \\
\hline 15 & Siswa O & 63 & & $\mathrm{~V}$ & 77 & V & & 83 & $\mathrm{~V}$ & \\
\hline 16 & Siswa P & 63 & & $\mathrm{~V}$ & 63 & & V & 80 & $\mathrm{~V}$ & \\
\hline 17 & Siswa Q & 51 & & V & 63 & & V & 80 & $\mathrm{v}$ & \\
\hline 18 & Siswa $\mathrm{R}$ & 63 & & V & 63 & & V & 65 & & V \\
\hline 19 & Siswa $\mathrm{S}$ & 72 & $\mathrm{~V}$ & & 72 & V & & 80 & $\mathrm{~V}$ & \\
\hline 20 & Siswa T & 54 & & $\mathrm{~V}$ & 60 & & $\mathrm{~V}$ & 82 & $\mathrm{~V}$ & \\
\hline 21 & Siswa U & 59 & & $\mathrm{~V}$ & 65 & & $\mathrm{~V}$ & 80 & $\mathrm{~V}$ & \\
\hline 22 & Siswa V & 76 & $\mathrm{~V}$ & $\mathrm{~V}$ & 78 & V & $\mathrm{V}$ & 82 & $\mathrm{~V}$ & \\
\hline 23 & $\begin{array}{c}\text { Siswa } \\
\text { W }\end{array}$ & 61 & & $\mathrm{~V}$ & 69 & $\mathrm{~V}$ & & 85 & $\mathrm{~V}$ & \\
\hline 24 & Siswa X & 62 & & $\mathrm{~V}$ & 63 & & $\mathrm{~V}$ & 87 & $\mathrm{v}$ & \\
\hline 25 & Siswa Y & 85 & $\mathrm{~V}$ & & 86 & V & & 88 & $\mathrm{~V}$ & \\
\hline 26 & Siswa Z & 77 & V & & 78 & $\mathrm{~V}$ & & 82 & $\mathrm{~V}$ & \\
\hline 27 & $\begin{array}{c}\text { Siswa } \\
\text { AB }\end{array}$ & 63 & & $\mathrm{~V}$ & 70 & $\mathrm{~V}$ & & 85 & $\mathrm{~V}$ & \\
\hline 28 & $\begin{array}{c}\text { Siswa } \\
\text { AC }\end{array}$ & 58 & & $\mathrm{~V}$ & 64 & & $\mathrm{~V}$ & 65 & & $\mathrm{~V}$ \\
\hline 29 & $\begin{array}{l}\text { Siswa } \\
\text { AD }\end{array}$ & 54 & & $\mathrm{~V}$ & 65 & & $\mathrm{~V}$ & 86 & $\mathrm{v}$ & \\
\hline 30 & $\begin{array}{l}\text { Siswa } \\
\text { AE }\end{array}$ & 57 & & $\mathrm{~V}$ & 65 & & $\mathrm{~V}$ & 83 & $\mathrm{v}$ & \\
\hline 31 & $\begin{array}{l}\text { Siswa } \\
\text { AF }\end{array}$ & 73 & $\mathrm{~V}$ & $\mathrm{~V}$ & 79 & $\mathrm{~V}$ & $\mathrm{~V}$ & 80 & $\mathrm{~V}$ & \\
\hline 32 & $\begin{array}{l}\text { Siswa } \\
\text { AG }\end{array}$ & 59 & & $\mathrm{~V}$ & 66 & $\mathrm{~V}$ & & 84 & $\mathrm{~V}$ & \\
\hline 33 & $\begin{array}{c}\text { Siswa } \\
\text { AH }\end{array}$ & 60 & & $\mathrm{~V}$ & 65 & & $\mathrm{~V}$ & 82 & $\mathrm{v}$ & \\
\hline 34 & $\begin{array}{c}\text { Siswa } \\
\text { AI }\end{array}$ & 60 & & $\mathrm{~V}$ & 63 & & $\mathrm{~V}$ & 64 & & $\mathrm{~V}$ \\
\hline & $\begin{array}{c}\text { JUML } \\
\text { AH } \\
\text { NILAI }\end{array}$ & 2199 & 11 & 23 & 2353 & 15 & 19 & 2725 & 29 & 5 \\
\hline & NTASE & 64,67 & 32,35 & 67,64 & 69,20 & 44,11 & 55,88 & 80,14 & 85,29 & 14,70 \\
\hline & $\begin{array}{l}\text { RATA- } \\
\text { RATA }\end{array}$ & $\%$ & $\%$ & $\%$ & $\%$ & $\%$ & $\%$ & $\%$ & $\%$ & $\%$ \\
\hline
\end{tabular}




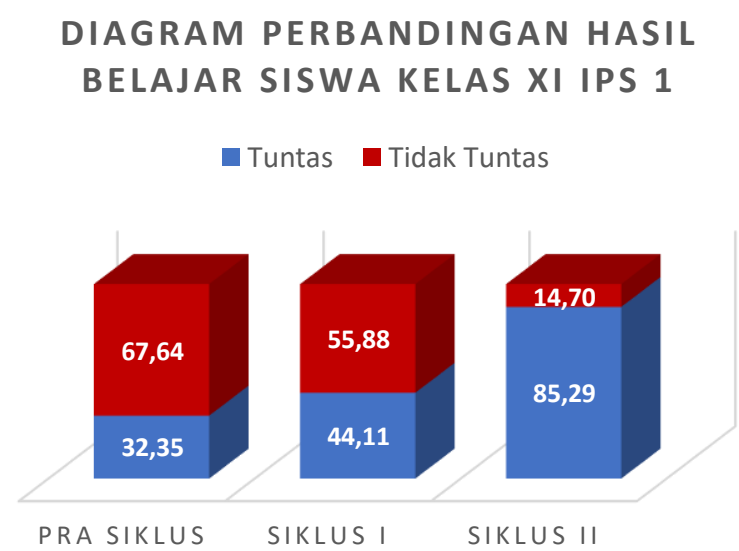

\section{Gambar 5. Diagram Perbandingan Ketuntasan Hasil Belajar Siswa Kelas XI IPS 1 pada Materi Bola Voli}

Berdasarkan analisa data pada tabel dan gambar diagram tersebut, dari penelitian ini dapat diketahui bahwa, penerapan metode simulasi pada pembelajaran mata pelajaran PJOK dalam rangka meningkatkan kemampuan dan keterampilan salah satu permainan bola besar (bola voli) siswa kelas XI IPS 1 SMA Negeri 1 Dawarblandong Mojokerto tahun pelajaran 2019/2020 terbukti meningkat. Dari hasil observasi awal atau hasil pra siklus ketuntasan belajar siswa pada kemampuan pengetahuan dan praktik keterampilan hanya 32,35\% meningkat menjadi $44,11 \%$ pada siklus I, sehingga diperlukan tindak lanjut pada siklus II dan pada siklus II ini mengalami peningkatan signifikan menjadi sebesar 85,29\%. Hal ini menunjukkan bahwa pada siklus II ini sudah mencapai dan melebihi ketentuan yang telah ditetapkan oleh sekolah yaitu ketuntasan belajar siswa yaitu $80 \%$.

Data yang telah diperoleh menunjukkan bahwa setelah diterapkannya metode simulasi, maka terbukti adanya pengaruh yang positif dalam meningkatkan kemampuan dan keterampilan salah satu permainan bola besar (bola voli). Karena adanya pengaruh positif metode pembelajaran simulasi dalam rangka meningkatkan kemampuan dan keterampilan salah satu permainan bola besar (bola voli) siswa kelas XI IPS 1 SMA Negeri 1 Dawarblandong Mojokerto tahun pelajaran 2019/2020, maka pengajar sekaligus penulis dapat memberikan beberapa harapan kepada guru atau tenaga pengajar lainnya untuk dapat menerapkan metode simulasi ini dalam rangka meningkatkan kemampuan dan keterampilan salah satu permainan bola besar (bola voli) pada mata pelajaran Pendidikan Jasmani Olahraga dan Kesehatan (PJOK). Dan juga diharapkan kepada siswa untuk terus mengulang-ulang metode simulasi untuk melatih kemampuan dan keterampilan salah satu permainan bola besar (bola voli) agar semakin memahami ilmu pendidikan jasmani, olahraga, dan kesehatan yang dipelajari.

\section{KESIMPULAN}

Berdasarkan hasil penelitian yang telah diuraikan di atas, maka kesimpulan pada penelitian tindakan kelas (PTK) dalam rangka peningkatan kemampuan dan keterampilan salah satu permainan bola besar (bola voli) siswa kelas XI IPS 1 SMA Negeri 1 Dawarblandong Mojokerto tahun pelajaran 2019/2020 dengan teknik análisis kualitatif diperoleh hasil bahwa terbukti dengan penerapan metode simulasi mampu meningkatkan kemampuan dan keterampilan penguasaan materi dan teknik dasar salah satu permainan bola besar (bola voli) dengan baik sehingga dapat memenuhi ketentuan yang telah ditetapkan oleh sekolah yaitu dengan ketuntasan belajar sebesar $80 \%$. 


\section{DAFTAR PUSTAKA}

Arikunto. (2006). Metode Penelitian Kualitatif. Jakarta: Bumi Aksara.

Hidayat, M.Taufik . (2015). Peningkatan Kemampuan Pass Bawah dalam Permainan Bola Voli Melalui Latihan Pass Bawah dengan Berjalan pada Siswa Kelas VI SDN Tanggul Wetan 01 Jembar._@ Pancaran, Vol.4, No.1, Hal 153-164.

Mukhlis, A. (2000). Penelitian Tindakan Kelas. Makalah Panitia Pelatihan Penulisan Karya Ilmiah untuk Guru se-Kabupaten Tuban, 5.

Nasional, D. P. (2003). Kurikulum Pendidikan Jasmani. Jakarta: Depdiknas.

Ahmad, Nuril. (2007). Panduan Olahraga Bola Voli. Surakarta: Era Pustaka Utama.

Pardjono, H. T. (2011). Bolavoli. Surabaya: Unesa University Press.

Salmi. (2018). Penerapan Metode Simulasi dalam Meningkatkan Kemampuan Teknik Dasar Permainan Bola Besar pada Siswa SMP Negeri 4 Siak Hulu. Jurnal Manajemen Pendidikan dan Pelatihan, 1.

Sudjana, N. (2013). Dasar-Dasar Proses Belajar Mengajar. Bandung: Sinar Baru Algensindo. hal 89.

Sugiyanto. (1995). Metodologi Penilitian. Surakarta: UNS Press: Hal 61.

Suherman, L. \&. (2000). Strategi Belajar Mengajar Pendidikan Jasmani dan Kesehatan. Pendidikan Dasar dan Menengah, 1.

Yusmar, Ali. (2017). Upaya Peningkatan Teknik Permainan Bola Voli Melalui Modifikasi Permainan Siswa Kelas X SMA Negeri 2 Kampar. Jurnal Pendidikan dan Pengajaran Program Studi Pendidikan Guru Sekolah Dasar FKIP Universitas Riau, Volume 1, Nomor 1 . 